Ulrik Franke:

\title{
Disconnecting digital networks: A moral appraisal
}

\begin{abstract}
:
Governments who feel threatened are known to disconnect "their" digital networks from the rest of the world, attempting to limit communication by blocking domain names, by disabling telephone networks, and sometimes by trying to isolate an entire country from the Internet. Even though these censorship processes are far from transparent, previous research by Howard et al. 2011 has identified two major self-professed reasons why governments take such actions: (i) protecting political authority and (ii) preserving the public good. This article examines these reasons from the point of view of rights-based theories and utilitarianism to assess their normative force. Though exceptions exist, it is concluded that neither rights-based theories nor utilitarianism in general supports the disconnecting of digital networks to achieve these aims. This conclusion gains extra force as it is supported by two normally opposing normative theories.
\end{abstract}

\section{Agenda:}

Introduction

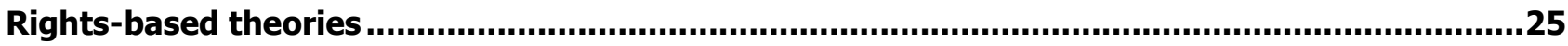

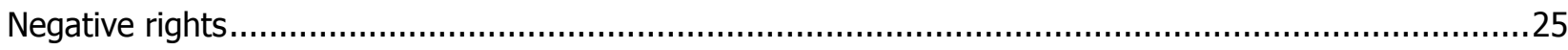

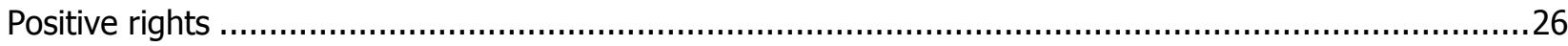

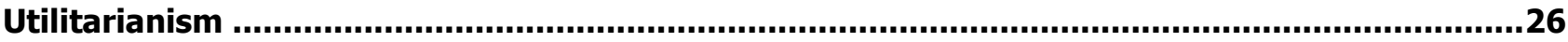

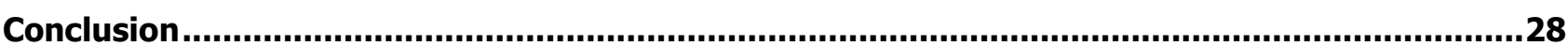

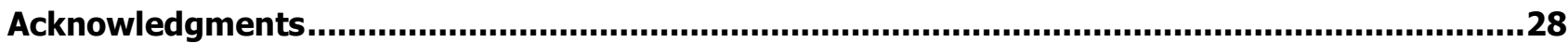

\section{Author:}

Dr. Ulrik Franke:

- Swedish Defence Research Agency (FOI), SE-164 90 Stockholm, Sweden

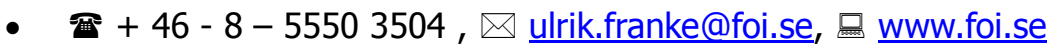




\section{Introduction}

President Mubarak's decision to "pull the plug" on the Egyptian Internet on the eve of his ousting attracted much attention and almost universal condemnation. However, Mubarak's action was just the tip of an iceberg. As shown by Howard et al 2011, recent years have seen at least 80 incidents annually where governments have "intervened" in a digital network by breaking or limiting connections between national sub-networks and global information networks. The cases range from the Egyptian attempt at an all-out blackout, through blocking all content on specific domains such as Facebook or YouTube to shutting down SMS services.

The Turkish blocking of YouTube and thousands of other websites is a case in point. The now infamous law No. 5651 was enacted in May 2007, in response to derogatory videos featuring Mustafa Kemal Atatürk, the founder of the Turkish republic. Up until December 2009, about 3700 websites were blocked under this law (Akdeniz, 2010). The YouTube block was lifted in November 2010 after the disputed videos were removed or made unavailable from Turkey. Nevertheless, throughout the blocking regime, YouTube remained the eighth most accessed site in Turkey, due to the popularity of circumvention techniques. As of February 2012, over 15000 sites remained blocked in Turkey, a country deemed "partly free" with regard to Internet freedom by Freedom House (Kelly et al., 2012).

A more recent case is the August 2012 riots in India's Assam region, where text messages and websites allegedly were used to stir violence between ethnic groups, precipitating the deaths of some 80 people and the displacement of 400 000-500 000 others. Reportedly, images of victims from 2008 Cyclone Nargis in Myanmar were presented as bodies of Muslims killed in Assam. The Indian government claimed that many of the forged websites were based in Pakistan and asked for Pakistani help in shutting them down. When Pakistan failed to cooperate, India ordered more than 250 websites blocked, and asked telecom providers to restrict the number of text messages distributed. Despite this, the images went viral (The Economist, 2012). When the media reviewed the list of websites ordered blocked, it turned out that a mere fifth of them actually contained references to Assam (The Indian Express, 2012).

Based on an analysis of 566 such "incidents", Howard et al. 2011 identified two dominant reasons used by governments to motivate their disconnecting digital networks: (i) protecting political authority (e.g. the Atatürk case) and (ii) preserving the public good (e.g. the Assam region case). This article analyzes these reasons from the perspectives of two normative theories: moral rights and utilitarianism, in order to assess their normative force.

The methodological rationale for this approach is that if two competing theories, despite their differences on many issues, give similar verdicts on governments disconnecting digital networks, then this result merits particular attention. In this case, as we shall see, neither rights-based theories nor utilitarianism lends any particular support to the arguments used by governments to motivate shutting down digital networks. (Cf. Carens 1987 for an example of an article adopting a similar methodology.)

Utilitarianism finds no intrinsic value in existing political authority. Such institutions have only instrumental value, naturally subsumed into the preserving the public good case. Conversely, theories of moral rights are not concerned with public good, but with individual rights. The analysis therefore unfolds with an emphasis on one normative theory for each reason. 


\section{Rights-based theories}

\section{Negative rights}

We start out from the perspective of negative moral rights in the tradition of Locke and Nozick, to analyze the case of protecting political authority. Here, the property rights of internet service providers, telecommunications companies, and website owners offer strong protection against state interference. Indeed, government activity is legitimate only when directed at preventing or rectifying rights violations. Therefore, when the police plan to arrest a thief or murderer, negative rights plausibly warrant temporarily disconnecting digital networks in order to prevent the felon from being warned. Similarly, in a just war a state may justifiably and temporarily disable digital networks in order to avoid their exploitation by the enemy (cf. e.g. the 2003 US Information Operations Roadmap and its now infamous recurring catch-phrase "fight the net"). However, there are crucial limitations. While the police may plausibly silence someone shouting a warning to a felon minutes before his apprehension, general rumors about police investigations, people too distant to warn the murderer, or criticism ex post may not be silenced. Such opinions and expressions are fully protected within the rights to free speech inherent in a negative rights conception.

Preventing the spread of "state secrets" is widely cited subcategory of the protecting political authority rationale. We have seen that protecting citizens against rights infringements does make moral room for "state secrets", e.g. the location of the police minutes before an apprehension, the location of military units in a just war, and plausibly also aspects of criminal investigation procedures and military intelligence. However, the legitimacy of these secrets is fully contingent upon the legitimacy of the activities they protect. State activities that do not protect negative rights cannot spawn legitimate state secrets. Therefore, states that engage in unjust wars of aggression have no right to stop anyone from revealing the locations of their military units, and police about to apprehend dissidents in repressive states have no right to silence warnings. Indeed negative rights theory, since John Locke, holds that a government does not hold any authority except for that which has been delegated by its citizens, and if that authority is abused there is a right to revolution. Subcategories of protecting political authority such as eliminating propaganda (the example of Howard et al. 2011 is Chinese crackdowns on democracy activists) and election crisis (the example of Howard et al. 2011 is the Iranian Twitter shut-down following the election result widely deemed fraudulent, cf. also Kelly \& Cook 2011 and Deibert \& Rohozinski 2010) therefore receive no support from theories of moral rights.

The subcategory of protecting political leaders and state institutions is more complicated. Individual negative rights can warrant temporary coercive action to protect individuals who are under a threat of imminent attack. Therefore, it is plausibly warranted to protect state officials (or indeed anyone) under imminent threat from remotely operated improvised explosive devices (IED) by shutting down a GSM network that could be used to detonate these devices (cf. Zorpette 2008 for more on the technical details). Nonetheless, such action must be temporary and in response to imminent threats - once the threat is gone, service must be restored, and compensation must be paid to network owners. However, in practice, the more frequent case concerns information that smears the reputation or public image of officials/institutions. The example given by Howard et al. 2011 is a 2007 Kazakh shutdown of opposition websites because of published transcripts related to a personal conflict between authoritarian president Nazarbayev and his son-in-law. Another example is the blocking of Google in China based on "Evil Jiang Zemin" being one of the top results when googling the former president (Segev 2008).

It is sometimes held that there is a right to one's reputation, e.g. as articulated in Article 12 of the UN Universal Declaration of Human Rights: "No one shall be subjected to [...] attacks upon his honour and reputation". However, it is very doubtful that such rights are consistent with negative rights theory. The reason is simple: such rights would entail property rights in others' brains (to control reputation), or at least others' printing presses and internet connections (to control public image). More detailed accounts of reputation and slander under negative rights theory can be found in Rothbard 1998 (pp. 121-132) or Tännsjö 2010 (pp. 61-62). In short, under negative rights, free speech as embodied in property rights in equipment, distribution channels and bodies (brains) trumps any claimed rights against slander. In practice, Reporters without borders have voiced concern that "rights to be forgotten" (i.e. to have online content about oneself removed upon request) 
"would be hard to reconcile with online freedom of expression and information", echoing the negative rights concern that other rights constrain the possibility to have a right to one's reputation. However, even if a right against attacks upon honor and reputation is granted, an ex post legal process seems like a far better method of reconciliation than an ex ante action of disconnecting digital networks. An important argument for this position is that disconnecting digital networks is likely to violate the rights of (innocent) third parties as well, something which is avoided in an ex post legal process.

\section{Positive rights}

Under a theory of positive moral rights, where moral rights are not only rights to non-interference, but claimrights to material goods that others have to supply, there are some important differences. Most often, these rights are construed as welfare rights (such as basic sustenance and health care) that are to be supplied by others. However, it is also conceivable to claim positive rights to immaterial goods, such as a right to information. van den Hoven \& Rooksby (2008) can be said to adopt such a view when arguing that access to information is a Rawlsian primary good (cf. Rawls 1999), and that opportunities to acquire information therefore should be afforded to each person under the Rawlsian opportunity principle:

"Now if, in a society, a substantial proportion of information relevant to citizens' life planning is only accessible via information media, then, in that society, a guarantee of equal liberty to seek information will not be sufficient in itself to ensure that all citizens have access to all relevant information. In such a society, access to (often expensive and complex) information media will also be necessary for citizens to access much of the information relevant to their rational life planning. To put the point in general terms, ensuring a just distribution of information requires not only a just distribution of information liberties for all citizens, but also mechanisms to ensure that people's opportunities to exercise their information liberties are roughly equal."

Prima facie, of course, such a positive right to access information gives no justification for disconnecting digital networks; rather, it offers justification for the opposite. However, it could be argued that in order to ensure citizens' (equal) access to information relevant to their life planning, a government could be justified in disconnecting digital networks used to spread misinformation or propaganda that in fact makes life planning more difficult. Indeed, such an argument could be made all the more poignant by an appeal to the Rawlsian concern with the least advantaged: perhaps most citizens are not harmed by the prevalence of misinformation, but if a minority of exceptionally gullible people are, then removing the propaganda might not make the majority substantially worse off, but could entail a significant improvement to the most gullible.

However, such censorship based on the difference principle is not coherent with Rawls' theory of justice, because freedom of speech is protected by the liberty principle (cf. Rawls, p. 197), which is lexically prior to the difference principle. In practice, of course, such idealistic censorship is all too often reversed by regimes that ban unwanted information in favor of their own propaganda (cf. e.g. Zhao 2009 on the Chinese de facto state monopoly on online news services, and Lagerkvist 2008 on the Chinese establishment of agenda-setting state news agencies). To conclude, the proper Rawlsian way to deal with inequalities in information access is not to remove it from the advantaged, but to give it to the disadvantaged.

Nevertheless, a Rawlsian positive right to information access does offer one subtle argument in the direction of justifying governments' disconnecting digital networks: if internet service providers are state owned, the argument against disconnections that arises from private property rights becomes void.

\section{Utilitarianism}

A strong utilitarian argument for protecting a status quo (such as existing political authority) is that the (almost certain) upheavals of protest or outright revolution do not outweigh the (far from certain) benefits of a new order. Classic accounts for this position include Burke, and Hobbes who famously defends the incumbent government by comparison with anarchy, where life is "solitary, poor, nasty, brutish and short". However, 
even if it is assumed that these arguments against revolution as such are valid, it does not follow that state disconnections of digital networks have to be embraced. There are at least two reasons for this:

First, there is the possibility that suppressing dissent does not prevent the violent upheavals of a revolution, but merely postpones the inevitable, and indeed makes the convulsions to come even worse. Taleb \& Blyth (2011) recently argued for this position with reference to the Arab spring, claiming that the artificial suppression of volatility in the name of stability is a dangerous practice:

"Such environments eventually experience massive blowups, catching everyone off-guard and undoing years of stability or, in some cases, ending up far worse than they were in their initial volatile state. Indeed, the longer it takes for the blowup to occur, the worse the resulting harm in both economic and political systems."

If this line of reasoning is correct, it constitutes a major utilitarian reason for not suppressing opposition, and opposition communications e.g. by disconnecting digital networks, in the name of protecting political authority against opposition.

Taleb \& Blyth do not dwell on particular causal mechanisms that support their thesis, but at least one such mechanism has to do with how free speech (or more generally: free flow of information) could make a society more robust, in the sense of being resistant to subversion or propaganda. In a society where the flow of information is tightly controlled and only select material is revealed to the public eye, the effects of suddenly revealing information, true or false, previously unheard of are unpredictable. For example, dropping leaflets or sending text messages about the personal conduct of political leadership can be disrupting in a society where such criticism has always been suppressed. In societies with (relatively) free flow of information, on the contrary, there is typically plenty of material available suggesting that the existing order should be overthrown and that the incumbent politicians are "crooks and thieves" (to borrow a phrase popularly used in Russia about the ruling United Russia party). Thus, the disruptive potential of spreading such statements is not particularly high, entailing the robustness. An everyday parallel is how accumulated experiences contribute to making adolescents increasingly skeptical towards information in advertising as they grow older (Bousch et al., 1994) - whereas someone who has never experienced advertising is more susceptible to it. In a way, this is reminiscent of Mill's argument for free speech that by allowing falsehoods to be uttered, a "clearer perception and livelier impression of truth, produced by its collision with error" is gained (Mill, 1859). ${ }^{1}$

The second reason is that it could actually be counterproductive for a regime wishing to perpetuate itself to disconnect digital networks. The fall of the Mubarak regime is a case in point. It has been argued that "pulling the plug" on the internet actually provided an unintended rallying call to the opposition, accelerating the downfall of the regime (Hassanpour 2011). It has also been proposed, with reference to the situation in Russia, that allowing internet protests can be a way for a regime to allow citizens to "let off steam" in a controlled way, while being careful not to let online protests spill over into offline activity (Lipman \& Petrov 2010).

If any of these analyses are correct, then a utilitarian wishing to uphold stability for utility's sake should refrain from disconnecting digital networks.

However, utilitarianism might also embrace state disconnections of digital networks for reasons other than maintaining stability. These cases cannot be assessed without context: for each case it is a prima facie open empirical question whether the act maximizes utility or not, corresponding to the normative question of whether it is right to perform the act according to utilitarianism (a good discussion of this difficulty in applying utilitarianism is found in Gren 2004). Nevertheless, it can be observed that the consequences of digital disconnects can be dire - not only in terms of stability as argued above - but also in economic terms. Howard et al. (2011) note that Mubarak's interruption of digital services cost Egypt's economy at least $\$ 90$ million, but also more subtle actions - including regulations that enable latent future disconnects - entail costs. Wallsten

\footnotetext{
${ }^{1}$ There are also other societal virtues that entail similar robustness: Toleration leads to immunity against blackmail. Spies such as the British civil servant John Vassall (1924-1996) could not have been blackmailed into espionage by the USSR for fear of having their homosexuality exposed in a more tolerant society where homosexuality was both perfectly legal and generally accepted.
} 
(2005) finds that countries requiring formal regulatory approval for Internet Service Providers (ISPs) to operate have fewer Internet users and hosts than countries that do not require such approval. Shin et al. (2012) conclude that "The less rigorous the regulations, the higher Internet's contribution to economic growth". Ghose \& Rajan (2006) show that many IT security regulations have unintended adverse consequences, such as decreasing competition and productivity. While such arguments cannot be conclusive without a complete specification of the intended good, they show that the utilitarian wishing to promote the public good by disconnecting digital networks takes on a heavy burden of proof in ascertaining that the pros indeed outweigh the cons.

\section{Conclusion}

As observed by Howard et al. 2011 democracies and authoritarian states alike disconnect digital networks, and recent years have shown an increasing frequency of such acts. Even though the exact practices of filtering and online censorship often remain obscure - Kelly \& Cook note "the arbitrariness and opacity surrounding decisions to restrict particular content" in all countries - governments do offer (broad categories of) reasons for disconnecting digital networks. In this article, these reasons have been considered from the point of view of two different moral theories; moral rights theory and utilitarianism.

It is concluded that neither theories of moral rights nor utilitarianism generally support the reasons given by governments to disconnect digital networks, though exceptions exist. The fact that these theories, which are opposed to each other on many controversial issues, give similar results on the issue of disconnecting digital networks gives the result particular credibility. Of course, authoritarian regimes do not necessarily pay any attention to neither utility nor human rights. Instead, they might be more inclined towards theories like Carl Schmitt's political philosophy.

A natural course of future research would include assessing the issue from other perspectives, such as communitarianism or Hobbesian approaches. Equally important, however, is to counteract disconnections. The rights-inclined policy-maker might for instance pursue strengthened property rights for internet service providers whereas the utilitarian might promote free speech on-line in the interest of long-term utility even at the expense of short-term stability.

\section{Acknowledgments}

This article has benefitted from comments by Patrick Krassén, Elin Palm and Steven J. Savage. The conclusions, as well as any errors and omissions, are the author's.

\section{References}

Yaman Akdeniz, Report of the OSCE Representative on Freedom of the Media on Turkey and Internet Censorship, 2010, Organization for Security and Co-operation in Europe

David M. Boush, Marian Friestad and Gregory M. Rose, Adolescent Skepticism toward TV Advertising and Knowledge of Advertiser Tactics, Journal of Consumer Research, Vol. 21, No. 1 (Jun., 1994), pp. 165175

Joseph H. Carens, Aliens and Citizens: The Case for Open Borders, The Review of Politics, Vol. 49, No. 2 (Spring, 1987), pp. 251-273

Ronald Deibert \& Rafal Rohozinski, Control and Subversion in Russian Cyberspace in Ronald Deibert, John Palfrey, Rafal Rohozinski \& Jonathan Zittrain, (eds.) Access Controlled, MIT Press, 2010, pp 15-34

The Economist, A neglected crisis, Aug 25th 2012, available online: http://www.economist.com/node/21560901

U.S.A. Department of Defense, Information Operations Roadmap, October 2003 
Ghose, A., Rajan, U.: The Economic Impact of Regulatory Information Disclosure on Information Security Investments, Competition, and Social Welfare. In: Fifth Workshop on the Economics of Information Security (2006)

Jonas Gren: Applying Utilitarianism. The Problem of Practical Action-guidance. PhD thesis, University of Gothenburg, Acta Philosophica Gothoburgensia 17, 2004.

Navid Hassanpour, Media Disruption Exacerbates Revolutionary Unrest: Evidence from Mubarak's Natural Experiment (2011). APSA 2011 Annual Meeting Paper. Available at SSRN: http://ssrn.com/abstract $=1903351$

Thomas Hobbes, Leviathan, Project Gutenberg, 2009 (1651)

Jeroen van den Hoven \& Emma Rooksby, Distributive Justice and the Value of Information: A (Broadly) Rawlsian Approach in Jeroen van den Hoven \& John Weckert, Information Technology and Moral Philosophy, Cambridge University Press, 2008, pp. 376-396

Philip N. Howard, Sheetal D. Agarwal \& Muzammil M. Hussain When Do States Disconnect Their Digital Networks? Regime Responses to the Political Uses of Social Media, The Communication Review, 14:3, (2011), pp. 216-232

The Indian Express, No Assam mention in most blocked sites, Aug 22 2012, available online: http://www.indianexpress.com/news/no-assam-mention-in-most-blocked-sites/991360/0

Sanja Kelly \& Sarah Cook, Freedom on the Net 2011, 2011, Freedom House

Sanja Kelly, Sarah Cook \& Mai Truong, Freedom on the Net 2012, 2012, Freedom House

Johan Lagerkvist, Internet Ideotainment in the PRC: national responses to cultural globalization, Journal of Contemporary China, 17:54, (2008), pp. 121-140

Maria Lipman \& Nikolaj Petrov: Obsjtjestvo i grazjdane v 2008-2010 gg. [Society and Citizens 2008-2010], Carnegie Moscow Center Working Papers, nr. 3, 2010

John Stuart Mill, On Liberty, (1859), Longman, Roberts and Green. London

Robert Nozick, Anarchy, State, and Utopia, Basic Books, 1974

John Rawls, A theory of Justice, revised edition, Oxford University Press, 1999 (1971)

Reporters without borders, Internet enemies report 2012, March 2012

Murray Rothbard: The Ethics of Liberty, New York University Press, 1998 (1982)

Elad Segev: Search Engines and Power: A Politics of Online (Mis-) Information, Webology, Volume 5, Number 2, June, 2008

Ilsoon Shin, Jungsoo Park, Seonghoon Jeon: The Size, Effects, and Efficiency of Internet Economy in Korea, International Telecommunications Policy Review, Vol.19 No.2 June 2012, pp.33-67

Nassim Nicholas Taleb \& Mark Blyth: The black swan of Cairo. Foreign Affairs, 90(3):33-39, 2011

Torbjörn Tännsjö: Privatliv, Fri Tanke Förlag, 2010

Scott Wallsten: Regulation and Internet Use in Developing Countries, Economic Development and Cultural Change, Vol. 53, No. 2 (January 2005), pp. 501-523

Jinqiu Zhao, A Snapshot of Internet Regulation in Contemporary China: Censorship, Profitability and Responsibility, in Friederike Assandri and Dora Martins (editors), From Early Tang Court Debates to China's Peaceful Rise, ICAS / Amsterdam University Press, Amsterdam 2009

Glenn Zorpette, Countering IEDS, IEEE Spectrum, Volume: 45, Issue: 9, pp. 26 - 35, Sept. 2008 